\title{
Actor's Network of Stunting Prevention Program in Bandar Lampung City, Lampung, Indonesia
}

\author{
Feni Rosalia \\ Government Science Department \\ Lampung University \\ Lampung, Indonesia \\ feni.rosalia@ fisip.unila.ac.id \\ Yulianto \\ Public Administration Department \\ Lampung University \\ Lampung, Indonesia \\ yulianto@fisip.unila.ac.id
}

\author{
Tina Kartika \\ Communication Science Department \\ Lampung University \\ Lampung, Indonesia \\ tina.kartika@fisip.unila.ac.id \\ Jeni Wulandari \\ Business Administration Department \\ Lampung University \\ Lampung, Indonesia \\ jeni.wulandari@fisip.unila.ac.id
}

\begin{abstract}
Today, all government institution should work under volatile, uncertain, complex, and ambiguous (VUCA) environment. In this situation, each institution or domain policy is more dependent to each other and demanding more inter-government relationship or collaborative process to intervening various public affairs. This paper attempt to understanding the complexity of actor relationship to fighting stunting in the Bandar Lampung City (BLC), Lampung, Indonesia, using social network analysis (SNA) approach. The authors select informant purposively and construct relationship data based on depth interview. Gephi for Mac OS $X$ was used to visualize actor relationship and analyzing characteristic of network structure (i.e., network density, reciprocal relationship, and centrality). This article focused on to answer several questions: what are the characteristics of social networks in stunting prevention program? Who are the dominant actors in social networks in stunting prevention program? How many factions are there in social networks in stunting prevention program? Finally, the authors discuss practical and theoretical implications of the finding.
\end{abstract}

Keywords-collaboration, governance, health policy, Indonesia, Lampung, network, stunting

\section{INTRODUCTION}

Stunting is a very serious public health problem because of its impact on the future generation of the Indonesian nation. In contrast to the proportion of stunting in children under five in Indonesia within five years (2013 - 2018) which tends to decline (2013: $37.2 \%$, 2018: 30.7\%), the stunting rate in Lampung Province tends to increase from year to year. The stunting rate, which only reached $22.7 \%$ in 2015, increased to $31.6 \%$ in 2017 [1]. To seriously tackle stunting, the Government of Lampung Province (GoLP) has established the Lampung Stunting Agency (LSA) at the provincial government level. The members of LSA come from various elements of society, for example, bureaucrats, academics, associations of health workers, non-governmental organizations concerned with health issues, community organizations, and educational institutions.

Since 2020, following directions from the Central Government and the GoLP, the Government of Bandar Lampung Municipality (GoBLM) has designated five sub-districts (Panjang, Kota Karang, Kedaton, Susunan Baru, and Sukamaju) as locations for stunting prevention through specific and sensitive nutrition intervention programs. In the GoBLM, the Health Office of Bandar Lampung City (HOBLC) has become the leading sector to managing issues of community health and nutrition status. Through the HOBLC, the GoBLM has targeted a reduction in the proportion of stunting from $21.20 \%$ in (2016) to $18.00 \%$ (2021) [2].

In simple terms, stunting is the phenomenon of failure of a child's physical development due to malnutrition experienced by infants under five years or while still in the womb. Stunting, which has an impact on children's physical and cognitive growth [3], in the long run will affect the future of a nation in many sectors. People who grow short, of course, will have different physical abilities from residents of normal height. Indonesia will be transformed into a fairy tale inhabited by dwarf if most of the population is dwarfed. Because of its tremendous impact on the problems 
facing the nation, stunting is a public problem that must be intervened by the government.

Previous research has identified the factors associated with stunting. At the individual level, stunting is associated with low nutritional intake for pregnant women, nursing mothers and toddlers [4], maternal knowledge [5], marriage under 18 years old [6], nutritional knowledge [7]. Certain diseases, for example diarrheal diseases and acute respiratory infection (ARI) [6], can also increase the incidence of stunting. At the household level, the socioeconomic status of the family, for example the level of family welfare [8-10] or poverty [10]-[12], the level of parents education $[10,12-15]$, the level of family income and unemployment [16], family food security [17], dietary patterns of household members [18], [19], the role of grandparents living at home [20], autonomy of women in the household [21], are also associated with stunting.

Environmental factors also affect stunting, for example sanitation and drinking water facilities [22, 23], women empowerment and access to health schemes [15], healthcare facilities [24], and terrorism [25]. Included in environmental factors is the government's political commitment to allocate resources (for example, funds, medical personnel, supplementary food, bureaucratic networks, health services, etc.) to combat stunting. In Indonesia, for example, this commitment is realized by financing the Family Hope Program in the form of cash transfers that have the potential to reduce the probability of stunting $[26,27]$.

Several researchers have voiced the importance of preventing stunting with a collaborative [28] or multisectoral approach [22] that does not only focus on improving nutrition, but reaches broader development goals so that child growth can be maximized [12]. Apart from nutritional interventions for pregnant women and children under five, several programs have also contributed to the reduction of the incidence of stunting, for example nutrition counseling and education, monitoring of infant and child growth, immunization, sanitation, and social safety networks. The combination of these programs is only effective if accompanied by political commitment, community participation, and considering the program context [29].

Although the collaboration or network of actors is considered important, to the best of researchers' knowledge, there have not been previous studies that specifically elaborated the phenomenon of collaboration or actor networks for stunting prevention. Ideally, because of the stunting is a wicked problem, its prevention practices in Lampung City will be intersectoral (involving government actors, markets, and civil society) and inter-governmental (involving various levels of government) [30] which produces a network of actors. However, what, and how the characteristics of the network of actors to combat stunting still need to be proven empirically.
This research aims to analyze the network of actors in the prevention of stunting program in the BLC using social network analysis (SNA) approach. SNA is a scientific method developed by sociologists who borrow graph theory from the discipline of mathematics. According to Wetherell [31], SNA has four basic propositions. First, all actors in a social system are interdependent and not independent. Second, actor relations in the social system are important because they affect the flow of information and resources between actors. Third, the structure of actor relations or ties between actors will create obstacles and opportunities or facilitate actors to take individual or collective actions. Finally, the pattern of actor relations defines the social, economic, and political structures in the social system.

To describe a network of actors, SNA defines a network as a group of actors (nodes) that are connected (edges/arcs) to one another. Each actor has attributes (for example, gender, age, level of education, centrality) that influence a person's position in the network. However, similarity of attributes does not mean similarity in position in social networks. In contrast to research methods in general, SNA does not focus on the attributes of actors, but rather on the position of actors in the network. This is because a person's position in the network will greatly influence the various actions, opportunities and constraints they have [32], [33]. This idea was later used in some technical terms among SNA theorists to analyze actor networks, for example, centrality, closeness, betweenness, transitivity, clique, and so on [34].

\section{METHODS}

This study uses a SNA method which is a derivative of the quantitative-descriptive approach. Sources of data come from interviews with seven informants at the district and sub-district level. These informants are selected purposively and spread over four sub-districts (Pajang, Teluk Betung Timur, Kedaton, and Tanjung Karang Barat). These four sub-districts were chosen as research locations because they are the target areas for the stunting prevention program in the BLC. In addition to collecting socio-demographic data, each informant was asked to list ten names that most frequently contacted, either through formal or informal communication channels, when carrying out activities related to stunting prevention.

The data from the informants was converted into a matrix using Microsoft Excel so that it can be exported to Gephi (open-source software to handling SNA data). Apart from visualizing the actor network in preventing stunting, the researcher will also describe the structural attributes of this actor network through several indicators, for example, graph density and centrality. Researchers will also discuss the implications of the structural attributes of this actor network for the prevention of stunting in the BLC. 


\section{FINDINGS}

\section{A. The setting}

The BLC is one of the autonomous regions in Lampung Province which is located at $5^{\circ} 20^{\prime}-5^{\circ} 30^{\prime}$ South Latitude and $105^{\circ} 28^{\prime}-105^{\circ} 37^{\prime}$ East Longitude. Due to its status as the capital city of Lampung Province, the BLC is the center of economy, political center, center of various socio-cultural activities in
Lampung Province. The area of BLC reaches 197.22 $\mathrm{km}^{2}$ with a population of 1.1 million people [35]. Administratively, the BLC consists of 20 districts and 126 urban village. Among these sub-districts, since 2020, the GoBLM has designated 4 sub-districts and 11 urban village as the focus of stunting prevention: Teluk Betung Timur (3 urban village), Tanjung Karang Barat (2 urban village), Panjang (3 urban village), and Kedaton (3 urban village).

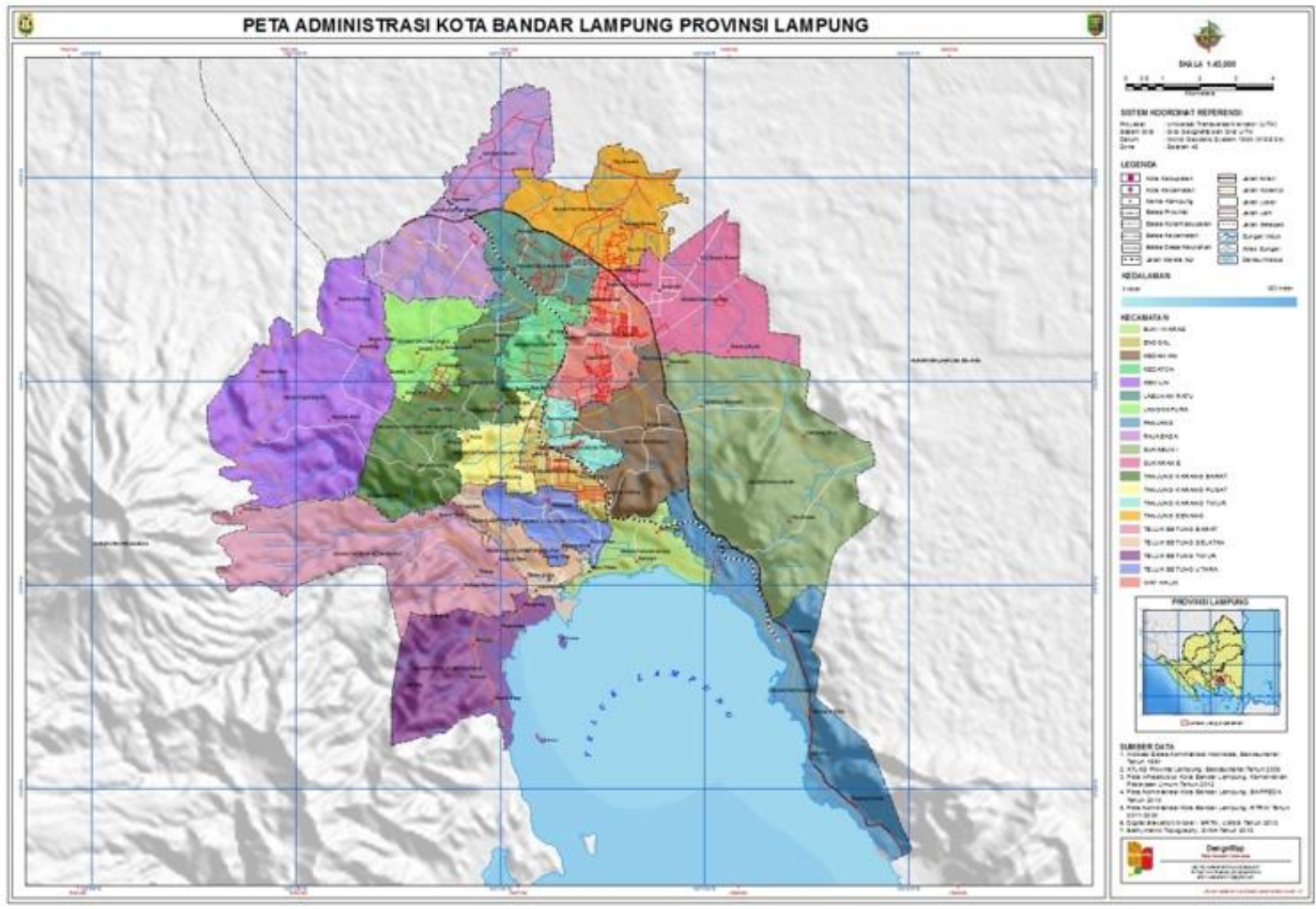

Fig. 1. Map of Bandar Lampung Municipality.

Like other districts/cities in Indonesia, the BLC has also been affected by COVID-19. The economic growth rate of BLC, for example, fell from 6.21 in 2019 to -1.85 in 2020 . Its PDRD (current price) decreased from IDR56,469.73 (2019) to IDR55,266.35 (2020). The open unemployment rate has also increased from $7.12 \%$ (2019) to $8.79 \%$ (2020). The number of poor people increased from $8.71 \%$ (2019) to $8.81 \%$ (2020). However, some macro indicators have increased several points, for example, the labor force participation rate increased from 65.52 to 67.79. Life expectancy also increased from $65.52 \%$ (2019) to $67.79 \%$ (2020). The Human Development Index (HDI) increased from 77.33 points to 77.44 points [35]. COVID-19 has caused the GoBLM to become unfocused on tackling stunting. Since COVID-19 was declared a pandemic, almost all the capacity of the health service system at the central and regional levels has been allocated for the COVID-19 emergency response.

As an illustration, currently the BLC has a morbidity rate of $9.43 \%$. This means that $9.43 \%$ of the population in the BLC has health complaints, both physical health and non-physical health. Efforts to reduce the morbidity rate involved 1,975 health workers consisting of: specialist doctors (332 people), general practitioners (501 people), dentists (79 people), and midwife ( 1,045 people). These health workers work in various health service units, for example, hospitals (12 units), maternity hospitals (7 units), community health center/Puskesmas (31 units), sub-community health center/Puskesmas Pembantu/Pustu (50), maternity clinics (6 units), clinics (73 units), integrated health post/Pos Pelayanan Terpadu/Posyandu (704 units) and eye hospital (2 units) [35]. 


\section{B. Characteristic of informant}

From seven key informants, the researcher found 83 (eighty-three) names of people involved in the stunting prevention actor network in the BLC. Of the total number of informants, $40(48.19 \%)$ were state civil servants (Aparatur Sipil Negara/ASN) and 43 $(51.81 \%)$ were non-state civil servants (non-ASN). Male informants reached $15(18.07 \%)$ and female informants amounted to $68(81.93 \%)$. The proportion of female informants was higher because the stunting program involved Posyandu institutions at the urban village level that were driven by women.

The mean of the informants age was 43 years (youngest: 22 years, oldest: 58 years) with a standard deviation (SD) of the respondent's age of 7.6 and a variance of 58.06 which indicates that the informant is in the productive age layer. Many informants only graduated from high school/equivalent (31 people/37.35\%). The rest are those who have successfully pursued undergraduate/equivalent (17 people/20.48\%), master's degree/equivalent (14 people/16.87\%), diploma III/ equivalent (14 people/16.87\%), junior high school/equivalent (4 people/4.82\%), and diploma IV/equivalent (3 people/3.61\%). Research informants have activities at village level institutions (Posyandu, Puskeskel/Pusat Kesehatan Kelurahan/ Village Health Post), subdistrict level (Puskesmas), and district level (agency/office in the GoBLM).

Most informants acted as Posyandu cadres (29 people/34.94\%). Some of the informants work as health workers, ranging from midwives (15 people/18.07\%), nutrition workers ( 7 people/8.43\%), and nurses (3 people/3.61\%). The rest are informants who work as bureaucrats, for example heads of offices/agency at the district level (8 people/9.64\%), heads of Puskesmas (6 people/ $7.23 \%$ ) and bureaucrats at the sub-district level (4 people/4.82\%), and the officials of urban village government (11 people/13.25\%). The composition of these informants implicitly describes the hierarchical structure of the network of institutions involved in the prevention and control of stunting in the BLC. The following descriptions will elaborate more deeply on the attributes of this institutional network.

\section{Structure of network}

Figure 2 shows a visualization of the network institutions of stunting prevention and control in the BLC. This network contains 83 nodes which is representing various institutions: Posyandu, Puskeskel, urban village government, Puskesmas, agencies/offices in the GoBLM. The network density is only 0.012 $(12 \%)$. It indicated that it is not too dense, or all actors have not been connected or forming an edge (relationship) to one another. This network has the potential to create $88 \%$ new edges between actors. In addition, there are four nodes representing Posyandu institutions that are not connected (isolation) to the main network. Although the data of this study were only in the form of purposive sampling, these findings indicate a phenomenon of social isolation or marginalization of actors who play a role in Posyandu institutions in preventing stunting in the BLC. Of course, it is outside the context of this research to answer how many Posyandu actors and institutions experience social isolation or marginalization in collective efforts to prevent stunting in the BLC.

Fig. 2. Structure of institution network in stunting alievating program at Bandar Lampung City 
Figure 2 shows the strategic roles of Bandar Lampung's Development Planning Agency (BLDPA) or Bandar Perencanaan Pembangunan Daerah (BAPPEDA) Kota Bandar Lampung and the HOBLC in preventing stunting at the city level. Implicitly, Figure 2 also confirms the perspective of the GoBLM which sees stunting as a health problem. This can be seen clearly from the central role of the HOBLC and its institutional networks in mobilizing resources related to stunting prevention, both at the sub-district and urban village levels. At the city level, the role of BLDPA remains strategic because of its ability to coordinate various cross-sectoral development programs that can be focused on preventing and overcoming stunting.

Because the BDLPA does not have a bureaucratic network at the sub-district/urban village level and the authority to execute programs, it can encourage several related technical agencies (for example, the Agency for Urban Village Community Empowerment Affairs, the Agency for Marine and Fisheries Affairs, the Agency for Agriculture Affairs, the Agency for Women's Empowerment and Child Protection Affairs) to mobilize bureaucratic networks and their resources to the urban village level for stunting prevention. However, this effort can only be done if the BLDPA, which has access to regional apparatus organizations at the city level, is able to frame stunting as not merely a health problem, but as a complex problem that needs to be approached from various development sectors.

If the label Figure 2 is replaced with individual professions (nodes) and reformatted according to the size of the Eigenvector Centrality (EC), it will be seen that the most influential profession in the network of stunting prevention actors in the BLC. The EC score is a measure to see how important the role of actors (nodes) in the network is based on the number of connections (edges) with other nodes. As Figure 3 shows, there are two professions that have $\mathrm{EC}=1$, namely: midwives and nutrition workers at the Puskesmas. This data reinforces previous findings regarding the perspective of the GoBLM which sees and approaches stunting as a health problem so that it stresses health resources (health workers and health facilities) as the spearhead of stunting prevention/control in the BLC.

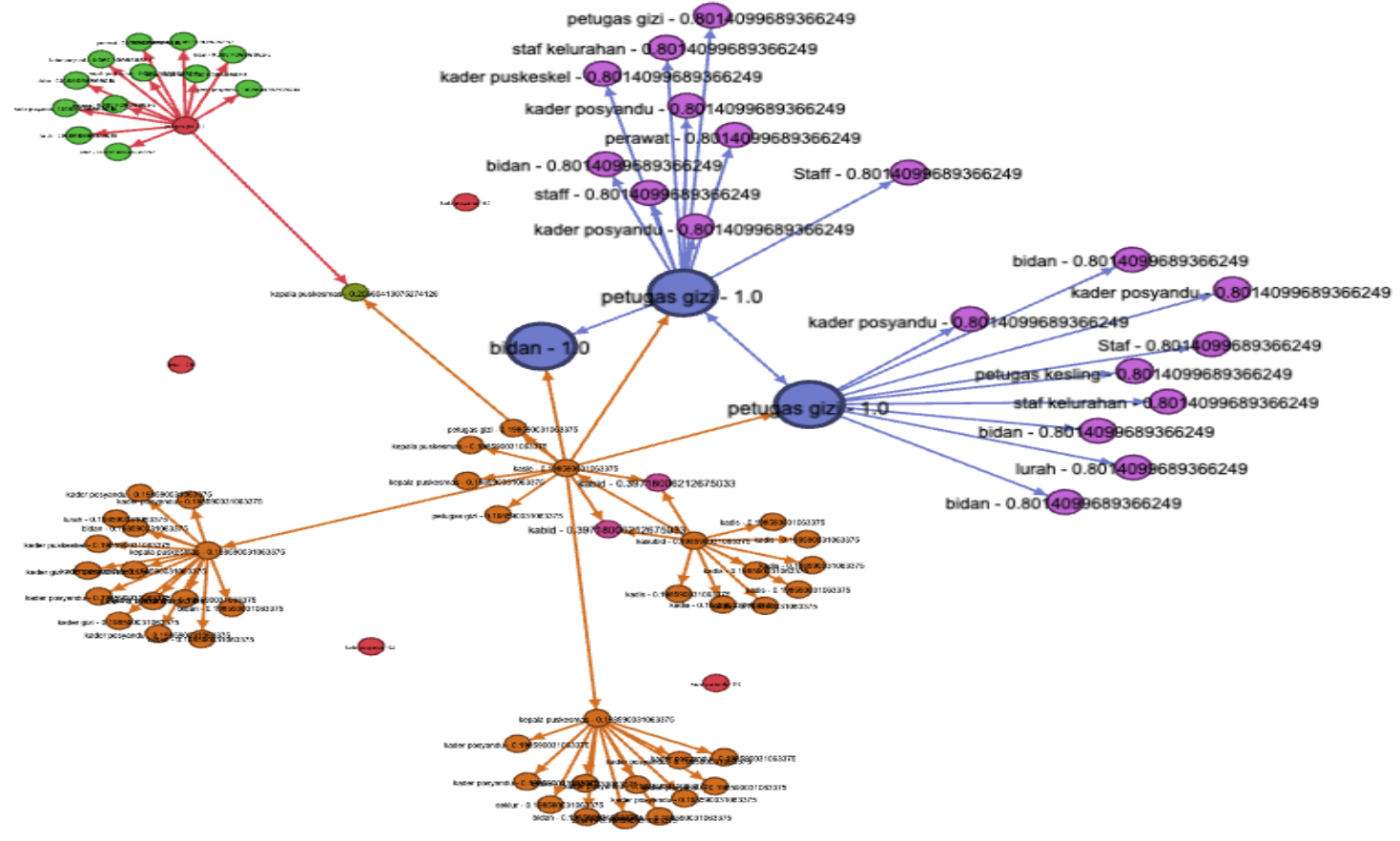

Fig. 3. Stunting's actor network based on eigenvector centrality score and profession.

The next profession which has an EC score $=0.8$ is shown by actors (nodes) in pink colors which are concentrated in two locations: Puskesmas Sukamaju and Puskesmas Susunan Baru. Although midwives and nutrition workers both have EC $=1$, Figure 3 shows how nutrition workers have social networks to various professions, ranging from bureaucrats at the city level, village officials, Posyandu cadres, and Puskeskel institutions.

Apart from EC, the influence of actors (nodes) in the network can be explained by the betweenness centrality (BC) indicator which explains how actors (nodes) control or mediate the relationship between a pair of actors who do not have a direct relationship (edge). The higher the actor's BC score, the more strategic position of an actor (node) and the higher the potential to control interactions that occur in a network. Figure 4 shows how the HOBLC. is the most influential actor in the stunting prevention actor network in the BLC. This is because the HOBLC can control $54 \%$ (score $\mathrm{BC}=54$ ) of interactions in the stunting actor network in the BLC. The second position was occupied by Puskesmas Susunan Baru and Puskesmas Panjang which were able to control interaction in the network by $28 \%$ (score $\mathrm{BC}=28$ ). The next position was occupied by Puskesmas Sukamaju (score BC =27), Puskesmas Kota Karang (score BC $=24$ ), and the BLDPA (score $\mathrm{BC}=8)$. 


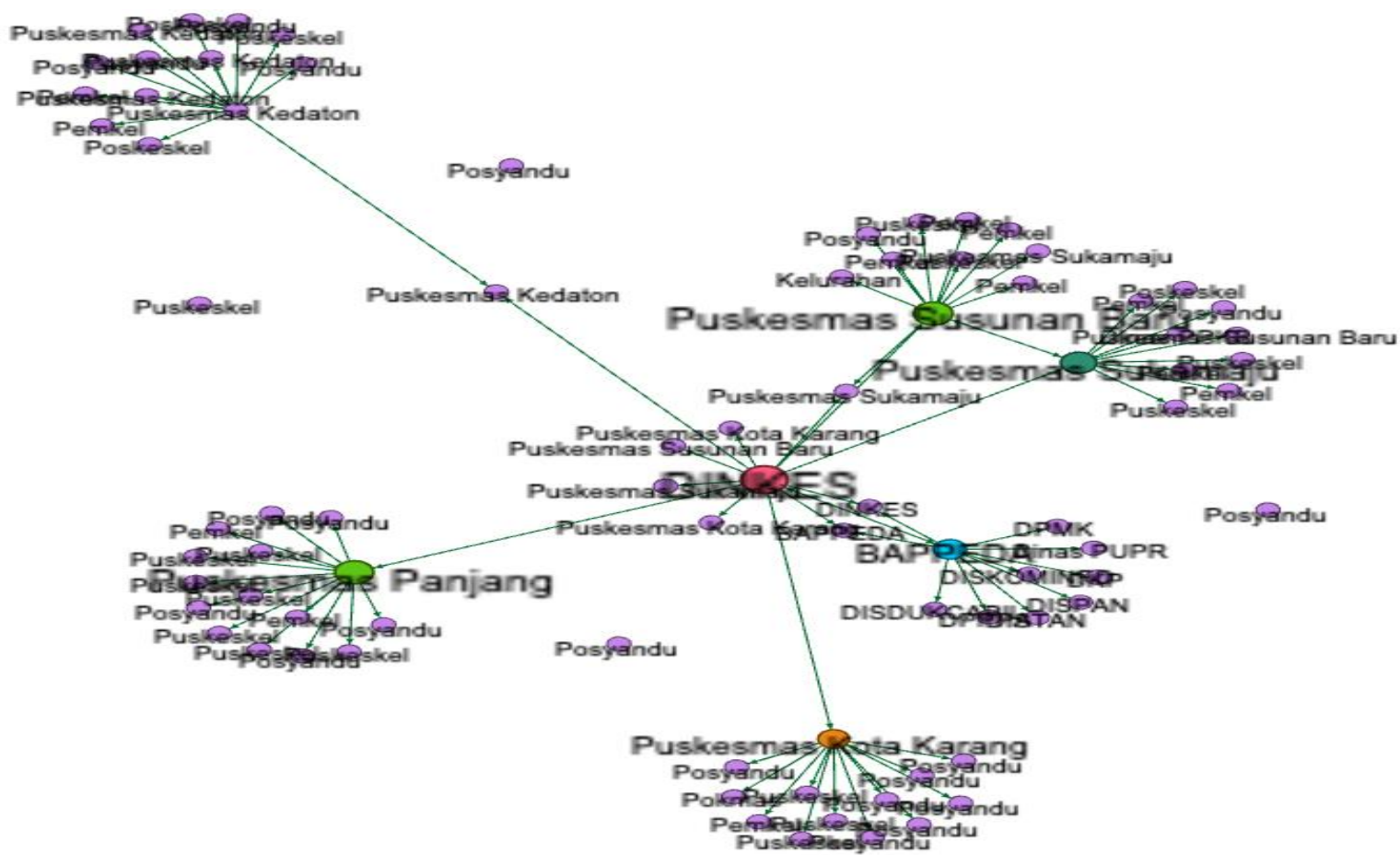

Fig. 4. Structure of institution networkn in Bandar Lampung City based on betweeness centrality score.

The third indicator that can explain the influence of actors (nodes) in the network of stunting prevention in the BLC is closeness centrality (CC). The greater the $\mathrm{CC}$ score, the closer an actor (node) is to another actor (node) in an actor network. Physical proximity will provide various benefits to an actor, for example getting information earlier, making the exchange process faster, and being able to communicate directly with other actors without intermediaries. Referring to Figure 5 , if viewed from the $\mathrm{CC}$ indicator, there are several actors who have influence in the network of stunting prevention actors in Bandar Lampung, namely: Puskesmas Panjang $(\mathrm{CC}=1)$, Puskesmas Kota Karang
$(\mathrm{CC}=1)$, Puskesmas Kedaton $(\mathrm{CC}=1)$, Puskesmas Susunan Baru $(\mathrm{CC}=0.68)$, Puskesmas Sukamaju $(\mathrm{CC}$ $=0.66)$, the HOBLC $(\mathrm{CC}=0.55)$, and the BDLPA $(\mathrm{CC}$ $=0.38)$. The high CC score of the Puskesmas institution is very logical. This is because the Puskesmas at the sub-district level plays the role of brokerage that connects actors at the village level with actors at the district level. Puskesmas must interact downward (urban village level) and upward (district level). With this position, the Puskesmas has closeness to actors in the urban village level as well as actors at the district level. Consequently, his CC score is greater than that of other actors. 


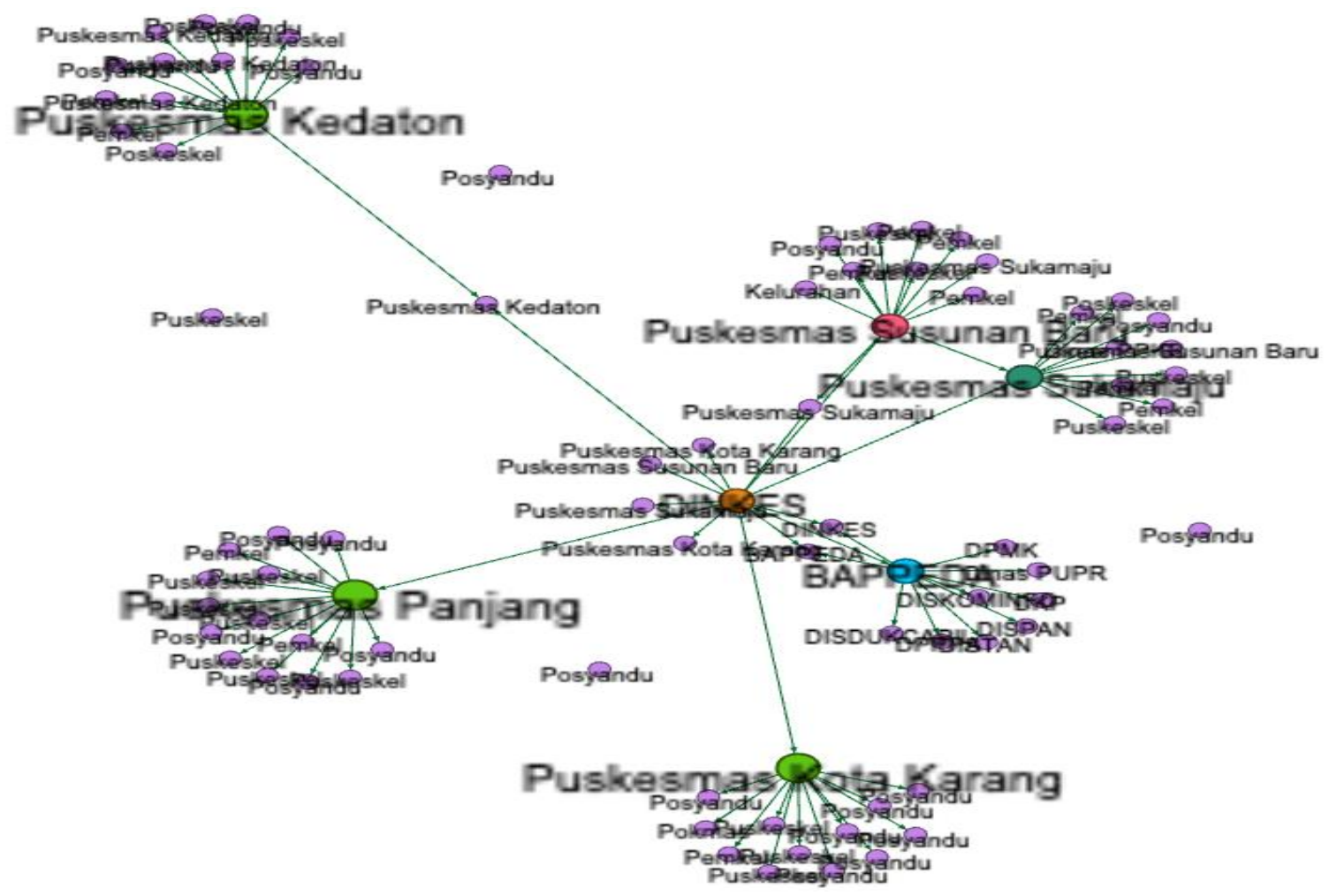

Fig. 5. Structure of institution networkn in Bandar Lampung City based on closeness centrality score.

Women (pink color) are the spearheads of stunting prevention and control in the BLC. All grassroots institutions, especially Posyandu and Puskeskel, which act as the spearhead of stunting prevention/control in the BLC, are occupied by women (pink color). In contrast, most of the structural equivalent of Echelon II at district level and involved in preventing stunting were male (Figure 6).

Figure 6 shows the phenomenon of gender bias in preventing stunting in the BLC, especially at the grass roots. Because stunting is a child health problem and caring for children is the responsibility of women, then women are dominant in stunting prevention programs at the grassroots level. If stunting is a matter of nutritional intake, then stunting is closely related to the level of family income which - in the cultural context of Indonesia and Lampung Province - is the responsibility of men. If the family income is low, then the family's ability to meet quality nutritional intake is also low. If men do not know and are not aware of the importance of nutrition for the growth of children under five, then how can they prioritize daily expenditures for improving children's nutrition. 


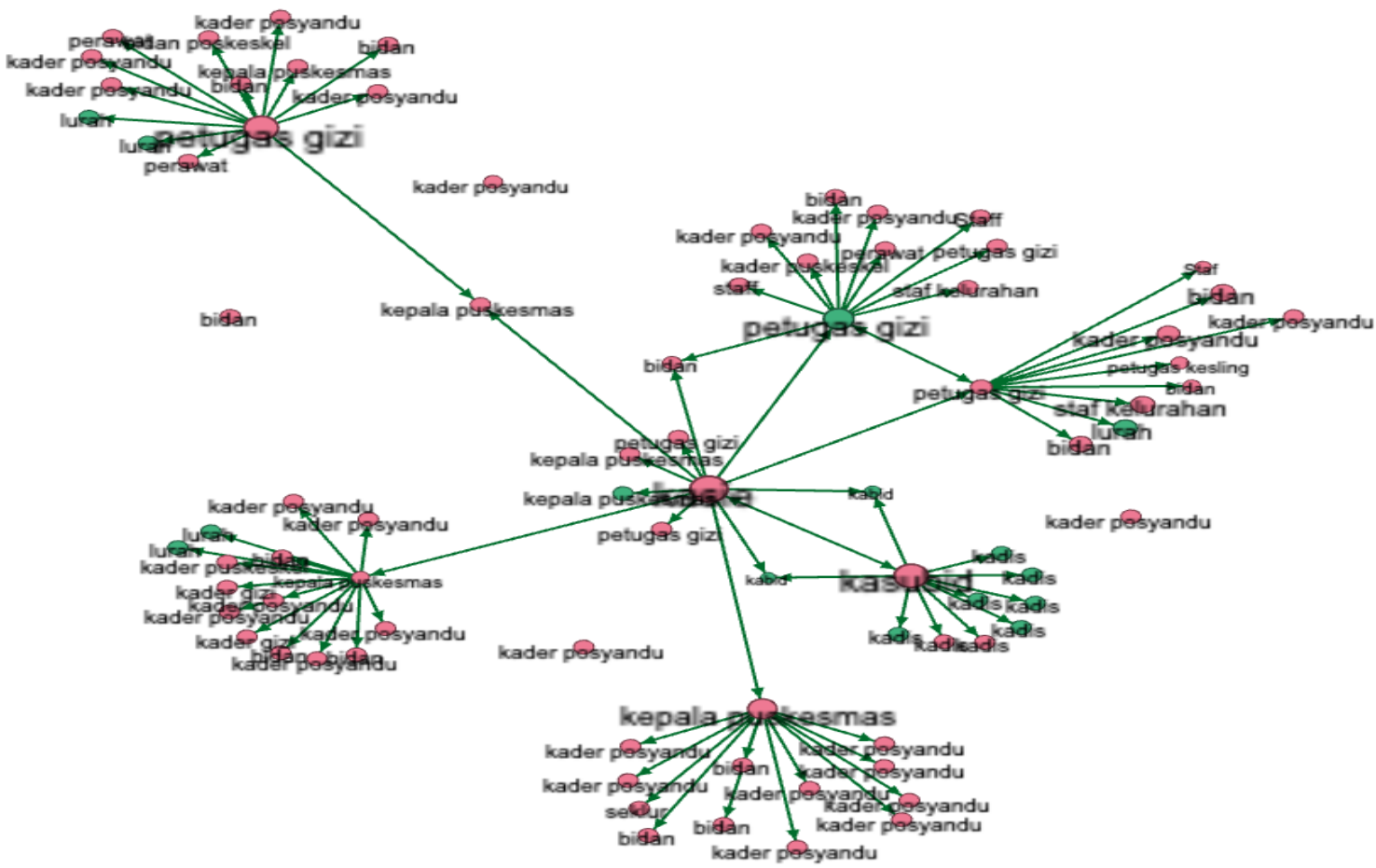

Fig. 6. A network of stunting actors based on profession and gender.

Finally, as shown in Figure 7, the main occupational backgrounds of informants involved in stunting prevention can be grouped into three categories: state civil servants (48.19\%), non-state civil servants $(39.76 \%)$, and honorary employees (12.05\%). Many non-state civil servants in Posyandu is housewives. Figure 7 shows the strategy of the the GoBLM in dealing with stunting that combines a bureaucratic or top-down approach and a voluntary or bottom- up approach. The bureaucratic approach relies on the resources owned and allocated by the GoBLM. Meanwhile, the voluntary approach rests on the resources in the community. However, the results of interviews with several informants show how actors at the grassroots are very dependent on the flow of resources from the GoBLM. In other words, efforts to generate voluntary strategies in preventing stunting have not yet grown and well developed. 


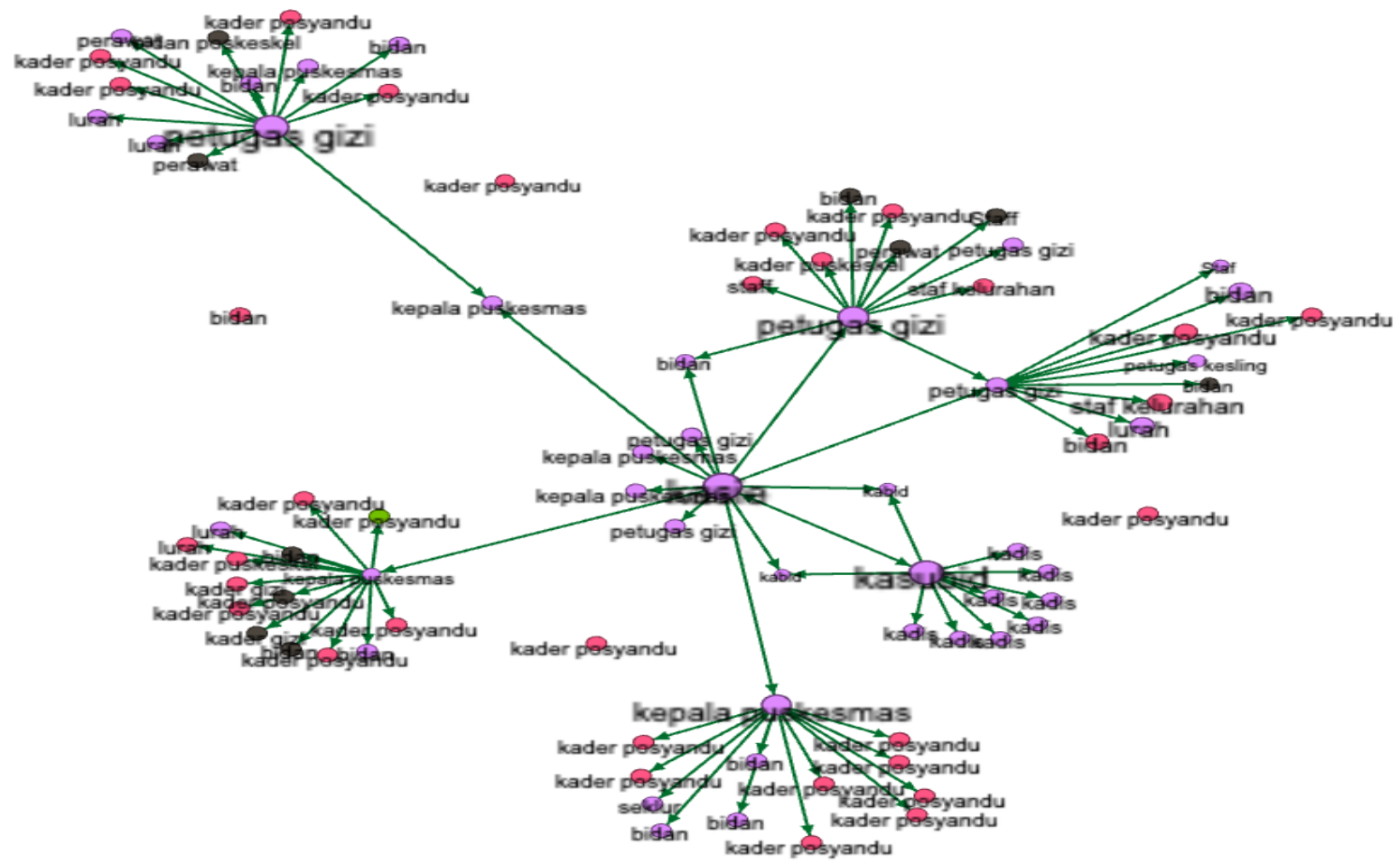

Fig. 7. A network of stunting based on type of actors primary employment.

\section{DISCUSSION}

This study found a network of actors, both individuals and institutions, who are involved in preventing stunting in the BLC. The density of this network is still low (12\%) and there are four actors in Posyandu institutions who experience isolation and/or marginalization because they are not connected to the main network. The pattern of actor network confirms the perspective of the GoBLM which sees stunting as a health problem, thus placing health resources (health workers and health facilities) as the spearhead of stunting prevention in the BLC. In fact, as revealed by previous studies, stunting contributors can be at the individual, family, and environmental levels.

Consequently, midwives and nutrition workers at the Puskesmas level are influential actors $(\mathrm{EC}=1)$ in this network. Although both have $\mathrm{EC}=1$, nutrition workers have social networks to various professions, ranging from bureaucrats at the district level, urban village officials, Posyandu cadres, and Puskeskel institutions, compared to midwives. If it is explained by the BC score, the HOBLC is the most influential actor in the network of stunting prevention actors in the BLC it is able to control 54\% (BC score $=54$ ) of interactions in the network. Meanwhile, if seen from the $\mathrm{CC}$ score, there are three actors who have influence in the network of stunting prevention actors in the BLC: Puskesmas Panjang (CC = 1), Puskesmas Kota Karang $(\mathrm{CC}=1)$, and Puskesmas Kedaton $(\mathrm{CC}=1)$. Although the GoBLM tries to combine top down and bottom-up approaches in preventing stunting, the grassroots actors are very dependent on the flow of resources from the GoBLM. Efforts to generate voluntary strategies are as hard as eliminating gender bias in stunting prevention.

The actor network pattern produced by this study is scientific evidence of collaborative practices for preventing stunting in the BLC. This phenomenon responds to several previous researchers' offer that stunting should be intervened with a collaborative approach [28]. Although the pattern of actor network also shows the existence of relationships between various development sectors at the city level, the facts on the ground still confirm the improvement of nutrition as the main weapon of preventing stunting in the BLC. This choice is a logical consequence of the perspective of the GoBLM who sees stunting as a health problem. In fact, several researchers have previously warned that stunting prevention should reach broader development goals so that child growth can be maximized [12].

The findings of researchers that placing Puskemas, midwives, and nutrition workers as influental actos in the networks reinforce the findings of previous studies on the strategic role of health facilities in stunting prevention [24]. On the other hand, the strong influence of the HOBLC in the network indicates the presence of the state or a political commitment among local political elites to prevent stunting. The work of the HOBLC at the district, sub-district and urban village levels has also demonstrated intergovernmental stunting prevention efforts in the BLC. However, unfortunately, this strategy is not yet inter- 
sectoral because it has not involved stakeholders from the market sector and civil society.

The health approach, especially nutrition improvement, adopted by the GoBLM in preventing stunting is in line with previous studies that emphasize factors at the individual level as contributors of stunting, for example nutritional intake for pregnant women, nursing mothers and toddlers [4], maternal knowledge [5], and nutritional knowledge [7]. However, stunting also involves factors at the household level (for example, the level of family welfare, household poverty [8-10], level of parent education [10], level of family income [16], and family food security [17]) and the environmental level (for example, sanitation and drinking water facilities [22, 23]) which have not received serious attention from the GoBLM. Integrating factors at the family level and the environmental level into stunting prevention policies requires the GoBLM to strengthen the collaboration of actors at all levels of government, including collaboration with market players and civil society organizations, which is currently still low.

Although this study succeeded in visualizing and elaborating the network of actors in preventing stunting in the BLC, this research still has several weaknesses. First, because it starts from the principle that the pressure point for regional autonomy is at the city/district level, the researchers ignore the possibility of a network formed between the GoBLM and the GoLP and the central government. Second, this research is only descriptive and does not test the strength of the relationship between actor (node) attributes and their role and position in the network that is formed. Third, the researches sample did not involve household members who used health services, either at Posyandu, Puskeskel, or Puskesmas. Researchers suggest that similar studies in the future can cover the three weaknesses of the research so that understanding of actor networks in preventing stunting can be better.

\section{ACKNOWLEDGMENT}

This research is a part of research on stunting prevention program in Bandar Lampung City, Lampung, Indonesia. The authors would like to thank for all research participant who willing to share their data, opinion, perception, and information on stunting program

\section{REFERENCES}

[1] Kementerian Kesehatan Republik Indonesia, Laporan Nasional Riset Kesehatan Dasar 2018. Jakarta, Indonesia: Kementerian Kesehatan Republik Indonesia, 2019.

[2] Dinas Kesehatan Kota Bandar Lampung, Rencana Strategis Dinas Kesehatan Kota Bandar Lampung. Bandar Lampung, Lampung, Indonesia: Dinas Kesehatan Kota Bandar Lampung, 2017.

[3] O. M. Onifade, J. A. Otegbayo, J. O. Akinyemi, T. A. Oyedele, and A. R. Akinlade, "Nutritional status as a determinant of cognitive development among preschool children in South-
Western Nigeria," Br. Food J., vol. 118, no. 7, pp. 1568-1578, Jul. 2016, doi: 10.1108/BFJ-11-2015-0445.

[4] S. M. Damanik, D. Wanda, and H. Hayati, "Feeding practices for toddlers with stunting in Jakarta: A case study," Pediatr. Rep., vol. 12(s1), no. 8695, pp. 18-22, Jun. 2020, doi: 10.4081/pr.2020.8695

[5] C. Starkweather et al., "An interpersonal nutrition campaign and maternal knowledge and childhood feeding practices: a case study from mothers in rural Indonesia," Arch. Public Heal., vol. 78, no. 62, pp. 1-6, Dec. 2020, doi: 10.1186/s13690-020-00444-9.

[6] Y. Efevbera, J. Bhabha, P. E. Farmer, and G. Fink, "Girl child marriage as a risk factor for early childhood development and stunting," Soc. Sci. Med., vol. 185, pp. 91-101, 2017, doi: 10.1016/j.socscimed.2017.05.027.

[7] H. Alderman and D. D. Headey, "How Important is Parental Education for Child Nutrition?," World Dev., vol. 94, pp. 448464, 2017, doi: 10.1016/j.worlddev.2017.02.007

[8] C. R. Titaley, I. Ariawan, D. Hapsari, A. Muasyaroh, and M. J. Dibley, "Determinants of the Stunting of Children Under Two Years Old in Indonesia: A Multilevel Analysis of the 2013 Indonesia Basic Health Survey," Nutrients, vol. 11, no. 5, p. 1106, May 2019, doi: 10.3390/nu11051106.

[9] J. Silber, "On inequality in health and pro-poor development: The case of southeast asia," J. Econ. Stud., vol. 42, no. 1, pp. 34-53, 2015, doi: 10.1108/JES-10-2013-0151.

[10] M. H. Pulok, M. N. U. Sabah, and U. Enemark, "Socioeconomic inequalities of child malnutrition in Bangladesh," Int. J. Soc. Econ., vol. 43, no. 12, pp. 1439-1459, 2016, doi: 10.1108/IJSE-03-2015-0065.

[11] S. Petrou and E. Kupek, "Poverty and childhood undernutrition in developing countries: A multi-national cohort study," Soc. Sci. Med., vol. 71, no. 7, pp. 1366-1373, 2010, doi: 10.1016/j.socscimed.2010.06.038

[12] D. J. Corsi, I. Mejía-Guevara, and S. V. Subramanian, "Risk factors for chronic undernutrition among children in India: Estimating relative importance, population attributable risk and fractions," Soc. Sci. Med., vol. 157, pp. 165-185, 2016, doi: 10.1016/j.socscimed.2015.11.014

[13] C. N. Rachmi, K. E. Agho, M. Li, and L. A. Baur, "Stunting, Underweight and Overweight in Children Aged 2.0-4.9 Years in Indonesia: Prevalence Trends and Associated Risk Factors," PLoS One, vol. 11, no. 5, p. e0154756, May 2016, doi: 10.1371/journal.pone.0154756.

[14] E. Bbaale, "Maternal education and child nutritional status: Evidence from Uganda," African J. Econ. Manag. Stud., vol. 5, no. 1, pp. 52-74, 2014, doi: 10.1108/AJEMS-06-2012-0040.

[15] K. S. Imai, S. K. Annim, V. S. Kulkarni, and R. Gaiha, "Women's empowerment and prevalence of stunted and underweight children in rural India," World Dev., vol. 62, no. June 2013, pp. 88-105, 2014, doi: 10.1016/j.worlddev.2014.05.001.

[16] Ramli, K. E. Agho, K. J. Inder, S. J. Bowe, J. Jacobs, and M. J. Dibley, "Prevalence and risk factors for stunting and severe stunting among under-fives in North Maluku province of Indonesia," BMC Pediatr., vol. 9, no. 1, p. 64, Dec. 2009, doi: 10.1186/1471-2431-9-64.

[17] T. Mahmudiono, T. Nindya, D. Andrias, H. Megatsari, and R. Rosenkranz, "Household Food Insecurity as a Predictor of Stunted Children and Overweight/Obese Mothers (SCOWT) in Urban Indonesia," Nutrients, vol. 10, no. 5, p. 535, Apr. 2018, doi: 10.3390/nu10050535.

[18] M. Sekiyama et al., "Double Burden of Malnutrition in Rural West Java: Household-Level Analysis for Father-Child and Mother-Child Pairs and the Association with Dietary Intake," Nutrients, vol. 7, no. 10, pp. 8376-8391, Oct. 2015, doi: 10.3390/nu7105399.

[19] D. K. Momanyi, W. O. Owino, A. Makokha, E. Evang, H. Tsige, and M. Krawinkel, "Gaps in food security, food 
consumption and malnutrition in households residing along the baobab belt in Kenya," Nutr. Food Sci., vol. 49, no. 6, pp. 1099-1112, 2019, doi: 10.1108/NFS-11-2018-0304.

[20] S. Schrijner and J. Smits, “Grandparents and Children's stunting in sub-Saharan Africa," Soc. Sci. Med., vol. 205, pp. 90-98, 2018, doi: 10.1016/j.socscimed.2018.03.037.

[21] C. Holland and A. Rammohan, "Rural women's empowerment and children's food and nutrition security in Bangladesh," World Dev., vol. 124, p. 104648, Dec. 2019, doi: 10.1016/j.worlddev.2019.104648.

[22] H. Torlesse, A. A. Cronin, S. K. Sebayang, and R. Nandy, "Determinants of stunting in Indonesian children: Evidence from a cross-sectional survey indicate a prominent role for the water, sanitation and hygiene sector in stunting reduction," BMC Public Health, vol. 16, no. 1, pp. 1-11, 2016, doi: 10.1186/s12889-016-3339-8.

[23] M. Muldiasman, K. Kusharisupeni, E. Laksminingsih, and B. Besral, "Can early initiation to breastfeeding prevent stunting in 6-59 months old children?," J. Heal. Res., vol. 32, no. 5, pp. 334-341, 2018, doi: 10.1108/JHR-08-2018-038.

[24] N. Aoun, H. Matsuda, and M. Sekiyama, "Geographical accessibility to healthcare and malnutrition in Rwanda," Soc. Sci. Med., vol. 130, pp. 135-145, 2015, doi: 10.1016/j.socscimed.2015.02.004.

[25] D. Grossman, U. Khalil, and A. Ray, "Terrorism and early childhood health outcomes: Evidence from Pakistan," Soc. Sci. Med., vol. 237, p. 112453, Sep. 2019, doi: 10.1016/j.socscimed.2019.112453.

[26] M. Aries, H. Hardinsyah, and H. Tuhiman, "Determinan Gizi Kurang dan Stunting Anak Umur 0 - 36 Bulan Berdasarkan Data Program Keluarga Harapan (PKH) 2007," J. Gizi dan Pangan, vol. 7, no. 1, pp. 19-26, Mar. 2012, doi: 10.25182/jgp.2012.7.1.20-27.
[27] M. F. Rizal and E. van Doorslaer, "Explaining the fall of socioeconomic inequality in childhood stunting in Indonesia," SSM - Popul. Heal., vol. 9, p. 100469, 2019, doi: 10.1016/j.ssmph.2019.100469.

[28] J. Jap, S. Sumarmi, and N. A. Damayanti, "Importance of collaborative intervention of Preconception Nutrition in Suppressing the Stunting case in East Nusa Tenggara, indonesia," Indian J. Public Heal. Res. Dev., vol. 10, no. 9, p. 698, 2019, doi: 10.5958/0976-5506.2019.02515.4.

[29] M. Hossain et al., "Evidence-based approaches to childhood stunting in low and middle income countries: A systematic review," Arch. Dis. Child., vol. 102, no. 10, pp. 903-909, 2017, doi: 10.1136/archdischild-2016-311050.

[30] F. S. Berry and R. S. Brower, "Intergovernmental and Intersectoral Management: Weaving Networking, Conctracting Out, and Management Roles into Third Party Government," Public Perform. Manag. Rev., vol. 29, no. 1, pp. 7-17, 2005.

[31] C. Wetherell, "Historical Social Network Analysis," Int. Rev. Soc. Hist., vol. 43, pp. 125-144, 1998.

[32] A. Marin and B. Wellman, "Social Network Analysis: An Introduction," in The SAGE Handbook of Social Network Analysis, J. Scott and P. J. Carrington, Eds. London, UK: Sage Publication Inc., 2011, pp. 11-25.

[33] J. Scott, "Social Network Analysis," Sociology, vol. 22, no. 1, pp. 109-127, Feb. 1988, doi: 10.1177/0038038588022001007.

[34] S. Wasserman and K. Faust, Social Network Analysis: Methods and Application. Cambridge, UK: Cambridge University Press, 1994.

[35] BPS-Statistics of Bandar Lampung Municipality, Bandar Lampung Municipality in Figures 2021. Bandar Lampung, Lampung, Indonesia: BPS Kota Bandar Lampung, 2021. 